\title{
Potential Role of Sequential Solid-State and Submerged-Liquid Fermentations in a Circular Bioeconomy
}

\author{
José Pablo López-Gómez * (D) and Joachim Venus \\ Leibniz Institute for Agricultural Engineering and Bioeconomy, 14469 Potsdam, Germany; \\ jvenus@atb-potsdam.de \\ * Correspondence: plopezgomez@atb-potsdam.de; Tel.: +49-(0331)-5699-857
}

check for updates

Citation: López-Gómez, J.P.; Venus, J. Potential Role of Sequential Solid-State and Submerged-Liquid Fermentations in a Circular Bioeconomy. Fermentation 2021, 7, 76. https://doi.org/10.3390/fermentation 7020076

Academic Editor: Frank Vriesekoop

Received: 19 March 2021

Accepted: 6 May 2021

Published: 11 May 2021

Publisher's Note: MDPI stays neutral with regard to jurisdictional claims in published maps and institutional affiliations.

Copyright: (c) 2021 by the authors. Licensee MDPI, Basel, Switzerland. This article is an open access article distributed under the terms and conditions of the Creative Commons Attribution (CC BY) license (https:// creativecommons.org/licenses/by/ $4.0 /)$.

\begin{abstract}
An efficient processing of organic solid residues will be pivotal in the development of the circular bioeconomy. Due to their composition, such residues comprise a great biochemical conversion potential through fermentations. Generally, the carbohydrates and proteins present in the organic wastes cannot be directly metabolized by microorganisms. Thus, before fermentation, enzymes are used in a hydrolysis step to release digestible sugars and nitrogen. Although enzymes can be efficiently produced from organic solid residues in solid-state fermentations (SsF), challenges in the development and scale-up of SsF technologies, especially bioreactors, have hindered a wider application of such systems. Therefore, most of the commercial enzymes are produced in submergedliquid fermentations $(\mathrm{SmF})$ from expensive simple sugars. Instead of independently evaluating SsF and $\mathrm{SmF}$, the review covers the option of combining them in a sequential process in which, enzymes are firstly produced in SsF and then used for hydrolysis, yielding a suitable medium for SmF. The article reviews experimental work that has demonstrated the feasibility of the process and underlines the benefits that such combination has. Finally, a discussion is included which highlights that, unlike typically perceived, SsF should not be considered a counterpart of SmF but, in contrast, the main advantages of each type of fermentation are accentuated in a synergistic sequential SsF-SmF.
\end{abstract}

Keywords: enzymes; enzymatic hydrolysis; solid-state fermentation; sequential process; biorefinery; filamentous fungi; circular bioeconomy

\section{Background}

Solid-state fermentation (SsF) can be defined as a process in which solid particles, with an inter-particle continuous gaseous phase, act either as the substrate or as inert solid support for the growth of microorganisms, in the absence or near absence of free water [1]. SsF takes place in nature for example during the decomposition of solid organic matter, but for millennia, humans have taken advantage of SsF, adapting it for the production of food and beverages as in the case of bread, cheese, tempeh, sake, soy sauce or during cacao and coffee processing [2].

Despite being a traditional and ancient known method, its recognition as a potential alternative for the synthesis of various chemicals in industry did not occur until a few decades ago [3]. Since the 1970s, when SsF was used for enhancing the protein content of cattle feed, the number of investigations in SsF has been continuously growing [4]. Furthermore, a recent analysis by Soccol et al. [5], has shown an increasing number of patent application in recent years. A total of $1303 \mathrm{SsF}$ patents were published in the period of 2011-2016, an average of 217 patents / year, a number thirteen times higher than in the period from 1991-2000 and almost double from 2001-2010. The total number of patents published for the period 2017-2020 was 1292, an average of 323 patents/year (search made in PATENTSCOPE database from World Intellectual Property Organization, using the words 'solid state fermentation' in 'Front Page' field [6]). These numbers suggest that progress has been made and that the trend in the development of technologies with commercial application will likely continue to increase. 
The pursuit and adoption of ideas for the sustainable production of chemicals, based on renewable materials, has only accentuated the relevance that research in SsF has. Specially, due to the capacity to use agricultural wastes and other solid biowastes in SsF, the role of this technology and its potential for waste management could become paramount in the circular bioeconomy. There are already several reviews available in the literature covering general SsF aspects [5,7-9], detailed design aspects [10-14], reviews dealing with products such as enzymes [15], secondary metabolites [16], polysaccharides [17], organic acids [18], bioproducts in general [19] and the valorisation of wastes and the application of SSF in biorefineries [1,15,19-24].

This review briefly covers the fundamentals of SsF, its perceived advantages and downsides (especially bioreactor underdevelopment). It highlights the key role that enzymes play in the bioconversion of the abundant agro-industrial and food wastes and, thus, in the future of the circular bioeconomy. Furthermore, this article aims to emphasize that, unlike typically seen, SsF should not be considered a counterpart of the most common submerged-liquid fermentation $(\mathrm{SmF})$. Instead, this review covers the idea presented by various authors of combining $\mathrm{SsF}$ and $\mathrm{SmF}$ in a sequential process. Such a synergistic process, in which enzymes are firstly produced in SsF and then used in a SmF, exploits the particular advantages of each type of fermentation while leaving behind some of their constrains.

\section{A General Description of Solid-State Fermentation}

\subsection{Predominant Features of SSF}

Several attributes have been described which make SsF an interesting technology for the treatment of solid organic wastes (Table 1) [2,5,7,13,24-27]. It is important to note that, typically, SmF is used as the reference point for evaluating SsF properties.

Table 1. Comparison between SsF and SmF features as described by several authors. The background colour indicates an advantage (green) or disadvantage (red) $[1,7,15,17,28-31]$.

\begin{tabular}{lll}
\hline Characteristic & SmF & SsF \\
\hline Culture medium (cost) & High & Low \\
Energy requirement & High & Low \\
Yield & Smaller & Greater \\
Wastewater generation & High & Low \\
Space required (bioreactor volume) & Large & Small \\
$\mathrm{O}_{2}$ mass transfer & Low & High \\
Contamination risk & High & Low \\
Temperature control & Easy & Difficult \\
Online control of parameters & Easy & Difficult \\
Nutrient and product regulation & Easy & Difficult \\
Product recovery and purification & Easy & Less easy \\
Technology development level & High & Low \\
Large scale bioreactors & Available & Limited availability \\
Fermentation time & Shorter & Longer \\
\hline
\end{tabular}

In general, the advantages linked to $\mathrm{SsF}$ are the result of its distinctive low water content. An environment in which water is not predominant, resembles natural growing environments and creates the perfect conditions for the proliferation of microorganisms, particularly filamentous fungi. Under such conditions, microbes can conquer practically any substrate and degrade it, even when nutrients are in low quantities. Furthermore, a low water level reduces the risk of contamination and evidently, represents less water expenditure. Additionally, an important feature usually overlooked, is that less water implies a smaller bioreactor volume which results in lower capital equipment cost [30]. Finally, in many cases, microbes can directly utilize the substrates, with minimal or no pretreatment. 


\subsection{The Challenge in Solid-State Fermentation-Underdevelopment of Bioreactors}

Despite the benefits that SsF has and the potential advantages of this technology, from the economic and waste management point of view, its application in industry is still rare [32]. Unlike other technologies with speedy expansion, industrial application of SsF has been limited mostly to the animal feed sector.

Unfortunately, the main challenges that $\mathrm{SsF}$ faces, derive from the low water content that it requires. In SmF, water accounts for most of the bioreactor's working volume, creating homogeneous conditions that facilitate mixing. Such homogeneity makes the simulation of SmF, modelling and design of bioreactors, as well as the control of the processes, possible. Conversely, SsF processes are highly heterogeneous. The combination of solid particles, with concentration gradients of nutrients, a gaseous inter-phase with volume changes during the process and the growth of microorganisms, creates an overly complex system. Moreover, unlike in $\mathrm{SmF}$ in which water is the predominant component, the type of solid substrates can vary in SsF. Therefore, even if an effective process is designed and developed for a specific substrate and set of conditions, the same process can be difficult to apply when for example, the substrate or the microorganism is changed.

Heterogeneity complicates the development of general mathematical models to describe the processes [33]. Furthermore, the control of fermentation parameters such as moisture content, temperature across the substrate, or $\mathrm{pH}$, is still an important challenge to overcome. As a result, the scale-up of many processes and the design and construction of large-scale bioreactors is still pending [19]. The moderate success in the design of SsF bioreactors is evidenced by the lack of their application in laboratory studies; or as stressed by Cerda et al. [9]., by the astonishing number of papers published reporting $5 \mathrm{~g} \mathrm{SsF}$ and the lack of more reports focused on serious process development and upscaling.

There are several SsF bioreactor models which have been described elsewhere $[1,7,11$, 13,14]. However, despite of reported advancements, many of the models have undergone little changes in the last 30 years or so. In 1993, Durand et al. [34] described some of the SsF bioreactor models available and potential designs. Interestingly, many of these models, are still appearing in up-to-date literature $[1,13,32,35]$. Furthermore, although many bioreactors have been designed and tested, it has been argued that the best attained results are still those obtained in the most traditional and simple tray bioreactors [9]. The majority of the few industrial scale SsF bioreactors are based on tray-bioreactors, with the most important example being the rotating tray-like bioreactor used in the production of soy sauce. Other bioreactor systems have been based on stacking many trays in a tower for the production of biopesticides (developed by the German company Prophyta [36]) or to produce metabolites (Plafractor ${ }^{\mathrm{TM}}$ by the Indian company, Biocon [37]). Nevertheless, only thin layers can be used in tray bioreactors to avoid overheating from occurring and to maintain aerobic conditions, thus these systems are restricted to only small volumes of solid substrates [1].

Without further and more convincing developments in the scaling-up of SsF bioreactors, the production of many low-value products, e.g., lactic acid or ethanol, can hardly be attractive. Perhaps, this is the reason why the production of enzymes, with a very high market value, is one of the most researched topics in SsF and also why other works are intensively focusing on the production of more specialized compounds such as antioxidant polysaccharides [17], antibiotics [16], aroma compounds [38,39], phenolic compounds [40], etc.

\section{Potential Role of Solid-State Fermentation in a Circular Bioeconomy}

\subsection{The Role of Enzymes in the Bioconversion of Organic Residues}

The production of materials and energy from renewable biological resources in biorefineries is the ultimate objective of the bioeconomy model. Although being a noteworthy objective, adhering to appropriate waste management routes is essential to make this type of production systems sustainable [41]. Thus, the integration of the circular economy concept within the bioeconomy, has been considered vital for its success [42]. It is expected 
that, the increase in population, together with the expansion of processes based on biomass, will continue the rising trend in the generation of solid organic residues [43]. Examples of solid organic residues are garden and parks waste, food and kitchen wastes, wastes from food processing plants, forestry and agricultural residues, manure, etc. [43]. Without appropriate methods for the treatment/valorisation of these wastes, the value of the bioeconomy model could be questioned [42].

Generally, organic solid residues, contain carbohydrates, in the form of complex polymers such as cellulose, hemicellulose, lignin, starch, pectin, etc [44]. Additionally, they can also contain lipids and proteins [43]. Due to this rich chemical composition, fermentation processes have been investigated to produce various chemicals using organic wastes as substrates. In most cases, however, the carbohydrates, lipids and proteins present in the wastes cannot be directly used by most microorganisms, or at least metabolized at efficient rates. Therefore, enzymes are applied to break-down the complex molecules into easily digestible sugars, fatty acids and nitrogen.

Unlike other hydrolytic methods, enzymatic hydrolysis shows some good features such as milder process conditions, high specificity, non-addition of harsh chemicals and that it does not generate growth inhibitory compounds [30,45,46]. Another key function of enzymes is the physical degradation of the solids. This transformation, resulting in a reduction of medium's viscosity, allows for agitation to occur more easily and for the utilization of common bioreactors $[47,48]$. Therefore, enzymatic hydrolysis has become a fundamental piece in bioprocess development, biorefineries and the circular bioeconomy model $[44,49]$. This crucial preliminary process, coupled with the massive production of organic residues, has expanded an already large enzymes market, valued at USD 9.9 billion in 2019, and expected to grow at a compound annual growth rate (CAGR) of 7.1\% from 2020 to 2027 [50].

Bacteria, yeast and filamentous fungi are used for the generation of a wide range of industrial enzymes, mostly in SmF, however, at remarkably high prices [51,52]. This is the result of several factors including complex production processes, which target highly pure enzymes and that utilize expensive simple sugars [30]. There are various attempts available in the literature that assess the enzyme costs share in biochemical conversion processes (for example 15-20\% for biofuels production [53]). Nevertheless, an exact calculation is complicated, and it has been acknowledged that the cost factor of enzymes in the process has previously been significantly underestimated [52]. Nowadays, enzyme price is recognised as one of the most important bottlenecks in the development of bioprocesses based on lignocellulosic materials $[52,54,55]$. One of the major expenses in the current enzyme production processes is the cost of glucose that can constitute $50 \%$ of the total cellulase production costs [56]. Additionally, it is somewhat paradoxical, that while organic residues are used as a substitute for simple sugars, the enzymes necessary to hydrolyse them are produced from simple sugars. Such model is in principle, not in-line with a circular bioeconomy. It is foreseeable that, as for first-generation biofuels, the general trend to utilizing wastes instead of simple sugars will also become commonplace for enzyme production.

Without a way for reducing enzyme costs, the future of biorefineries based on wastes and residues can be compromised. Big efforts have already been dedicated to the optimization of current enzyme production processes and strains to reduce costs, yet, without reaching economic feasibility. A direct approach to reduce costs is the on-site production of enzymes which circumvents the costs related to enzyme transport, purification and stabilization (Figure 1) [56]. Studies in on-site enzyme production and integrated production methods have shown savings from $30-70 \%$ when the latter is used [55,57]. In the integrated process, enzymes are produced onsite, using streams that can be residues or wastes. Another option for costs reduction is Consolidated BioProcessing (CBP). In CBP, the same fermenting microorganism is responsible for the production of enzymes for the hydrolysis, all in a single step. Nonetheless, a single microorganism able to achieve CBP effectively, is not yet available and the studies carried out so far have not reached industrial 
scale [56]. Ultimately, it has been suggested that the only way to overcome the issues is by genetic modification of microorganisms [58].

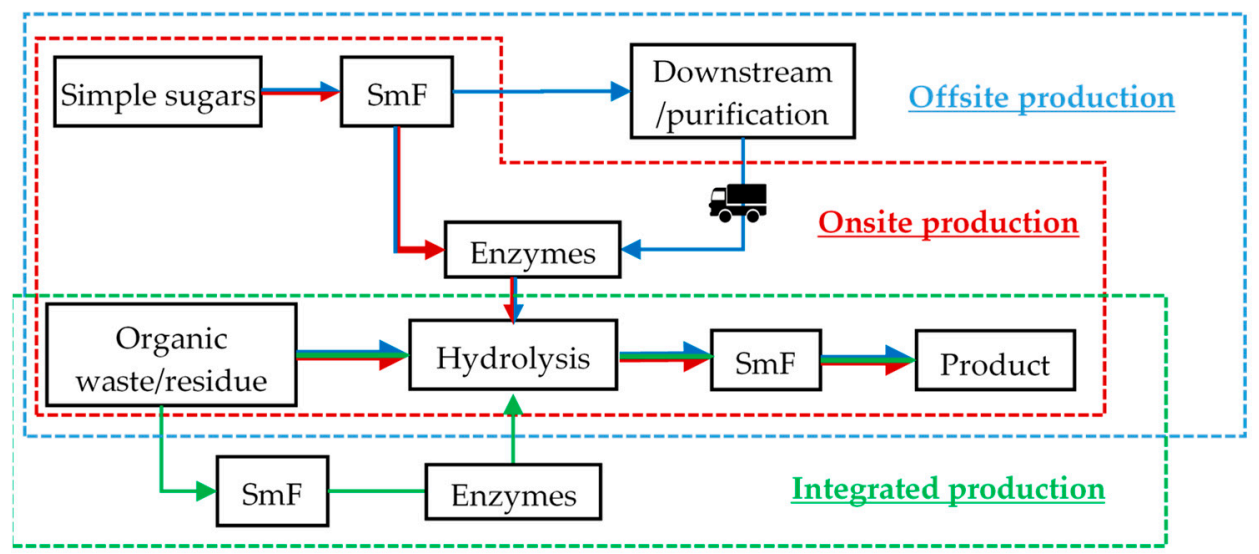

Figure 1. Diagram showing the common offsite production of enzymes (blue box and lines), onsite production of enzymes (red box and lines) and the integrated production of enzymes (green box and lines) as described by Johnson [57].

An alternative for further reducing enzyme production costs is the introduction of $\mathrm{SsF}$ in the integrated production diagram from Figure 1. Several studies, mostly at the lab scale, have shown that SsF offers appropriate conditions for the production of enzymes from solid wastes and residues [1,15,22,46,59-62]. Enzymes can be classified according to the type of substrate which they target and break-down into its basic building blocks [60]. Broadly, organic solid wastes and residues can be grouped into lignocellulosic or starchy materials, materials containing large amounts of proteins and lipids. Figure 2 shows some important enzymes in the decomposition of the different types or organic residues.

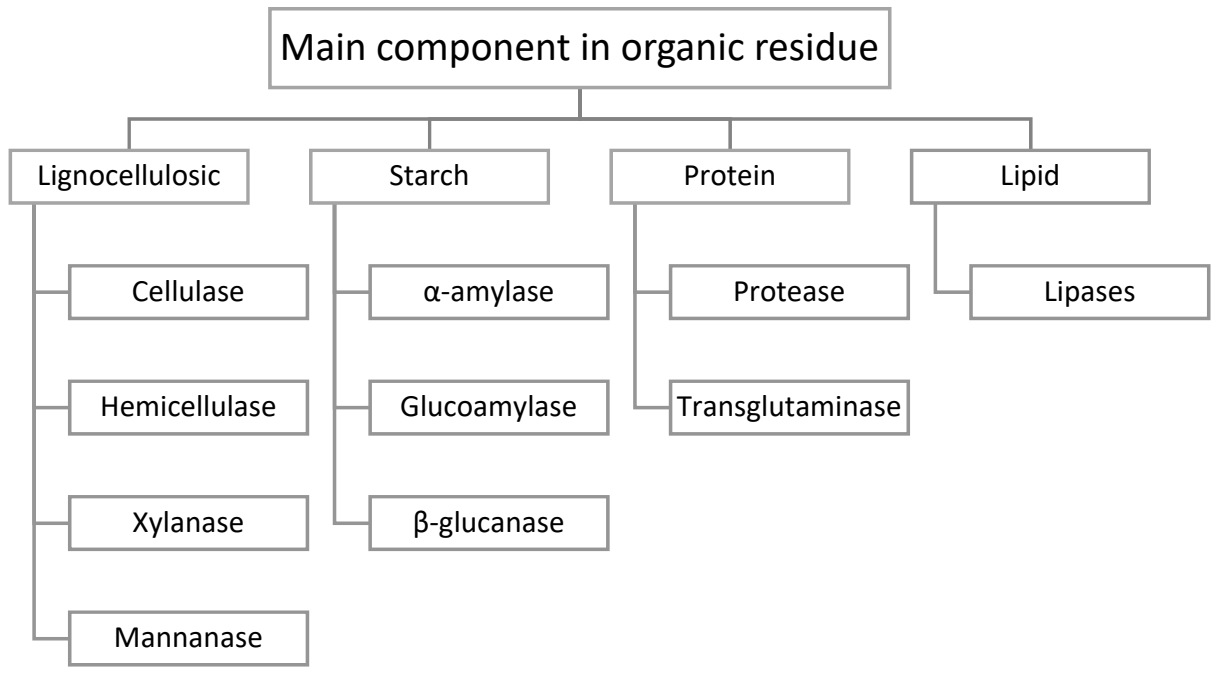

Figure 2. Main enzymes in the decomposition of organic solid residues.

\subsection{Sequential Solid-State Fermentation and Submerged-Liquid Fermentation}

The idea of coupling SsF and SmF in a sequential process has been used for millennia for example during the production of soy sauce. In the process, the soybean and wheat grains are firstly fermented, in a SsF, by microorganisms known as 'koji' in Japan. This first step is in-essence, a SsF and hydrolysis, where enzymes produced by koji break down the complex sugars in the grains and prepare them for subsequent SmF. Following this example, several authors have proposed similar processes in which SsF and SmF are combined, with the term 'sequential SsF-SmF' coined by Cunha et al. in 2012 [63]. Table 2 summarizes some of the results reported in the literature in this kind of process. 
Viesturs et al. [64], were one of the first authors to propose a combination of SsF and $\mathrm{SmF}$ in a process. They designed a bioreactor in which, in the upper section SsF was occurring while SmF was simultaneously carried out in the bottom of the bioreactor. In their system, steamed pre-treated wheat straw was fermented in SsF by cultures of Trichoderma reseei or Coriolus versicolor. A recirculation system was used to remove glucose and other metabolites from the SsF phase and transfer them to the SmF phase. The yeast, Endomycopsis fibuliger, was then used to consume the glucose generated in the SsF. Their study revealed that such system performed better in the production of cellular protein and cellulase activity, than the single individual SsF or SmF.

A similar system in which SsF was used for the production of a generic feedstock was presented by Botella et al. [65]. Utilizing a packed-bed bioreactor, pretreated wheat grains were fermented by Aspergillus awamori 2B. 361 U2/1. Amylolytic enzymes produced by the fungi degraded the starch into glucose while proteases converted proteins into free amino nitrogen. At intervals, an extraction was carried out with water, creating a medium rich in sugars and nitrogen which was used in two independent subsequent SmF for the production of polyhydroxybutyrate (PHB) (by Wautersia eutropha) and ethanol (by Saccharomyces cerevisiae). Remarkably, a maximum glucose concentration value of $177 \mathrm{~g} \mathrm{~L}^{-1}$ in the extract was achieved during SsF (6th day). Furthermore, the authors pointed out that a value of only $50 \mathrm{~g} \mathrm{~L}^{-1}$ was obtained when the same process was carried out in SmF [66]. Botella et al., explain that one of the main reasons for this difference is that, in the SmF systems, there is a maximum concentration of starch flour, which can be dissolved in water before too high viscosities are reached. This highlights a clear disadvantage of $\mathrm{SmF}$ compared to SsF in regard to how much glucose can be produced. Figure 3 shows the proposed diagram for the process [65] (based on the process by Webb and Wang, [67]). As explained by the authors, the addition of SsF reduces the complexity of the overall process by eliminating and combining some steps. As in [66], SsF is the cornerstone of this process, providing the required medium for the following SmF.

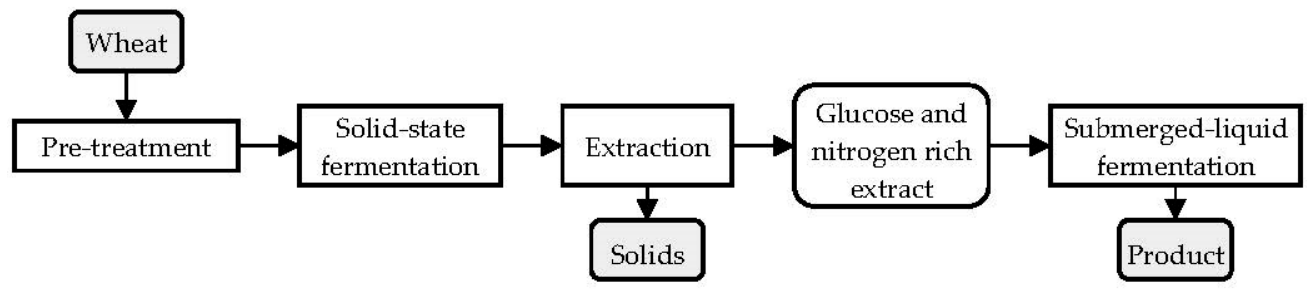

Figure 3. Example of a sequential SsF-SmF proposed in [65] for the production of a generic fermentation feedstock combining solid-state and submerged-liquid fermentations (adapted from [65]). 
Table 2. Studies carried out performing sequential solid and submerged fermentations.

\begin{tabular}{|c|c|c|c|c|c|c|c|c|c|}
\hline & SsF & & & Hydrolysis & & & $\mathrm{SmF}$ & & Ref $>0$ \\
\hline Substrate & Organism & Product & Enzyme Addition & Substrate & Product & Substrate & Microorganism & Product & Kert \\
\hline Wheat straw * & T. reesei or C. versicolor & Reducing sugars for SmF & - & - & - & Extract from the SsF & E. fibuliger & Protein & [64] \\
\hline \multirow{2}{*}{ Wheat grains } & \multirow{2}{*}{$\begin{array}{l}\text { A. azwamori } \\
\text { 2B.361U2/1 }\end{array}$} & \multirow{2}{*}{ Generic feedstock } & \multirow{2}{*}{ - } & \multirow{2}{*}{-} & & \multirow{2}{*}{ Extract from the SsF } & W. eutropha & PHB & \multirow{2}{*}{65} \\
\hline & & & & & & & S. cerevoisine & Ethanol & \\
\hline \multirow{2}{*}{ Wheat bran } & A. azamori & Glucoamylases & \multirow{2}{*}{ Enzyme extract } & Gluten-free flour & Glucose stream $\left(140 \mathrm{~g} \mathrm{~L}^{-1}\right)$ & \multirow{2}{*}{ Mixed glucose and nitrogen streams } & \multirow{2}{*}{ A. succinogenes ATCC 55618} & \multirow{2}{*}{ Succinic acid } & \multirow{2}{*}{ [68 } \\
\hline & A. oryzae & Proteases & & Gluten & Nitrogen stream $\left(3.5 \mathrm{~g} \mathrm{~L}^{-1}\right)$ & & & & \\
\hline \multirow{2}{*}{ Wheat bran } & A. azamori & Glucoamylases & \multirow{2}{*}{ SsF solids } & \multirow{2}{*}{$\begin{array}{c}\text { Wheat flour milling } \\
\text { by-product }\end{array}$} & \multirow{2}{*}{$\begin{array}{c}\text { Hydrolysate } \underset{\text { FAN) }}{\left(120 \mathrm{~g} \mathrm{~L}^{-1} \text { sugars, } 300 \mathrm{mg} \mathrm{L}^{-1}\right.} \\
\text { (1) }\end{array}$} & \multirow{2}{*}{$\begin{array}{c}\text { Wheat flour milling } \\
\text { by-product hydrolysates }\end{array}$} & \multirow{2}{*}{ A. succinogenes ATCC 55618} & \multirow{2}{*}{ Succinic acid } & \multirow{2}{*}{ [69] } \\
\hline & A. oryzae & Proteases & & & & & & & \\
\hline \multirow{2}{*}{ Waste bread } & A. avamori & Glucoamylases & \multirow{2}{*}{ SsF solids } & \multirow{2}{*}{ Waste bread } & Hydrolysate (over $100 \mathrm{~g} \mathrm{~L}^{-1}$ glucose, $490 \mathrm{mg}$ & \multirow{2}{*}{$\begin{array}{c}\text { Bread suspension } \\
\text { hydrolysate }\end{array}$} & \multirow[t]{2}{*}{ A. succinogenes } & \multirow{2}{*}{ Succinic acid } & \multirow{2}{*}{ [70] } \\
\hline & A. oryzae & Proteases & & & $\left.\mathrm{L}^{-1} \mathrm{FAN}\right)$ & & & & \\
\hline \multirow{2}{*}{ Bakery wastes (cake, pastry) } & A. avamori & Glucoamylases & \multirow{2}{*}{ SsF solids } & Pastry & $\begin{array}{l}\text { Hydrolysate }\left(44 \mathrm{~g} \mathrm{~L}^{-1} \text { glucose, } 715 \mathrm{mg} \mathrm{L}^{-1}\right. \\
\text { FAN })\end{array}$ & \multirow{2}{*}{$\begin{array}{l}\text { Pastry and cake } \\
\text { hydrolysates }\end{array}$} & A. succinogenes ATCC 55618 & Succinic acid & [71] \\
\hline & A. oryzae & Proteases & & Cake & $\begin{array}{l}\text { Hydrolysate (23.1 g L-1 glucose, } 388 \mathrm{mg} \\
\qquad \mathrm{L}^{-1} \text { FAN) }\end{array}$ & & & & \\
\hline $\begin{array}{l}\text { Nutrient solution }+ \text { sugarcane } \\
\text { bagasse }\end{array}$ & A. Niger A12 & SsF solids & - & - & - & SSF solids + glucose nutrient solution & A. Niger A12 & Cellulases & [63] \\
\hline Mixed food wastes & A. avamori & Glucoamylases & SeF solids $\mathrm{S}$ & Mired food wastes & Hydrolysate $\left(31.9 \mathrm{~g} \mathrm{~L}^{-1}\right.$ glucose, $280 \mathrm{mg} \mathrm{L}^{-1}$ & Food waste hydrolysate & $E_{\text {soli }}$ & Succininc acid & [72] \\
\hline Nined toud wases & A. oryzae & Proteases & Sor somidas & Nined rour wastes & FAN) & 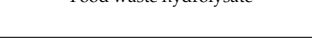 & ticut & & 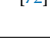 \\
\hline Sunflower meal & A. oryzae & Enzyme consortia & SSE solids & Sunflower meal & Nitrogen-rich & Nitrogen-rich hydrolysate + crude & C necetor DSM 545 & PHA & [73] \\
\hline Kitchen wastes & A. awamori & Glucoamylases & SsF solids & Kitchen waste & $\begin{array}{l}\text { Hydrolysate }\left(100.2 \mathrm{~g} \mathrm{~L}^{-1} \text { glucose, } 1081 \mathrm{mg}\right. \\
\mathrm{L}^{-1} \text { FAN) }\end{array}$ & Kitchen waste hydrolysate & L. cassi Shirota & Lactic acid & [75] \\
\hline Bakery wastes & A. oryzae & Proteases & & Kitchen waste powder & $\begin{array}{l}\text { Hydrolysate }\left(97.2 \mathrm{~g} \mathrm{~L}^{-1} \text { glucose, } 946.5 \mathrm{mg}\right. \\
\mathrm{L}^{-1} \text { FAN) }\end{array}$ & Kitchen waste powder hydrolysate & & & \\
\hline Wheat milling and flour-rich wastes & A. azuamori & Glucoamylases, proteases & SsF solids suspension & Flour-rich waste & $\begin{array}{l}\text { Hydrolysate }\left(168.9 \mathrm{~g} \mathrm{~L}^{-1} \text { glucose, } 937.2 \mathrm{mg}\right. \\
\left.\mathrm{L}^{-1} \text { FAN }\right)\end{array}$ & Flour-rich waste hydrolysate & Lipomyces starkeyi DSM 70296 & Microbial oil & {$[76]$} \\
\hline Rapeseed meal & A. oryzae & Hydrolytic enzymes & SsF solids suspension & SsF residue & 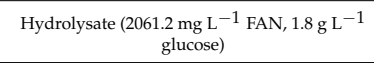 & Hydrolysate +glucose & S. cerevisiae & Dry yeast cells & [47] \\
\hline $\begin{array}{l}\text { Sugarcane bagasse }(60 \%)+\text { dry } \\
\text { spent grains }(40 \%)\end{array}$ & A. niger TK1 & Hydrolytic enzymes & $\begin{array}{c}\text { SsF solids } \\
\text { suspension }\end{array}$ & SsF residue & $\begin{array}{l}\text { Hydrolysate }\left(29.7 \mathrm{~g} \mathrm{~L}^{-1} \text { sugars, } 585.1 \mathrm{mg}\right. \\
\left.\mathrm{L}^{-1} \text { FAN }\right)\end{array}$ & Hydrolysate & S. cerevisiae TISTR 5339 & Ethanol & [77] \\
\hline Chlorella sp. TISTR 8411 biomass & Anaerobic granules & Dry residual biomass & - & - & - & Dry residual biomass hydrolysate & $\begin{array}{c}\text { Anaerobic } \\
\text { granules }\end{array}$ & Hydrogen & [48] \\
\hline
\end{tabular}

${ }^{*} \mathrm{SsF}$ and SmF occurring simultaneously in the same bioreactor 
The process from Botella et al. [65], has served as the basis for several other investigations using wastes and residues, instead of whole wheat, as feedstocks. Du et al. [68], showed how gluten and gluten-free flour from wheat, could be used for the production of succinic acid. To achieve this, wheat bran was firstly fermented in separate SsF by $A$. awamori and Aspergillus oryzae, to produce glucoamylase and proteases extracts, respectively. Then, the extracts were used to hydrolyze the flour and gluten suspensions. Concentrations of $140 \mathrm{~g} \mathrm{~L}^{-1}$ of glucose and $3.6 \mathrm{~g} \mathrm{~L}^{-1}$ of free amino nitrogen (FAN) were obtained in the flour hydrolysate and the gluten hydrolysate, respectively. The glucose and nitrogen enriched streams were then mixed and used in the production of succinic acid, reaching $22 \mathrm{~g} \mathrm{~L}^{-1}$ and increasing to $64 \mathrm{~g} \mathrm{~L}^{-1}$ when $\mathrm{MgCO}_{3}$ was supplemented to the medium. The authors proposed that besides providing $\mathrm{Mg}$ for the growth, the addition of $\mathrm{MgCO}_{3}$ makes $\mathrm{CO}_{2}$ more readily accessible in the broth, which could explain the enhancement. Moreover, they also suggested that a better approach could be adding the solid residues of the SsF directly to the flour and gluten suspensions, instead of extracting first the enzymes. This approach was tested by Dorado et al. [69], but instead of utilizing gluten free flour and gluten they used wheat flour milling by-products. The hydrolysis of wheat flour milling by-products, using the enzymes obtained in the SsF step, reached around $120 \mathrm{~g} \mathrm{~L}^{-1}$ of sugars and $0.3 \mathrm{~g} \mathrm{~L}^{-1}$ of FAN. Despite the lower FAN (compared to [68]), the subsequent SmF reached a higher succinic acid concentration $\left(50.6 \mathrm{~g} \mathrm{~L}^{-1}\right)$.

Leung et al. [70] and Zhang et al. [71], also showed the effective application of sequential SsF and SmF to produce succinic acid. A. awamori and oryzae were again used to synthesize amylases and proteases in the SsF of bakery wastes. Following the production of enzymes, the fermented solids ( $10 \mathrm{~g})$ were mixed with fresh bakery wastes $(300 \mathrm{~g})$ which had previously been blended with $1 \mathrm{~L}$ of water. Resulting hydrolysates from cake and pastry wastes, contained glucose 35.6 and $54.2 \mathrm{~g} \mathrm{~L}^{-1}$ and FAN 685.5 and $758.5 \mathrm{mg} \mathrm{L}^{-1}$, respectively. Subsequent $\mathrm{SmF}$ of these hydrolysates yielded succinic acid concentrations of 24.8 and $31.7 \mathrm{~g} \mathrm{~L}^{-1}$. The results highlight again the advantage of the SsF step, it not only provides adequate enzymes for the release of free sugars and FAN during hydrolysis, but it does so at appropriate concentrations. Furthermore, the authors underline the generic nature of the feedstock produced from bakery wastes and that succinic acid could be substituted by many other products.

The potential advantages of utilizing SsF and SmF in a sequential process, was further demonstrated by Sun et al. [72]. Bakery wastes (pastries) were utilized as the substrate for enzyme production in SsF. The crude enzyme source was then used for the hydrolysis. However, unlike in previous reports, the authors used a different waste, i.e., kitchen wastes, in the hydrolysis and subsequent $\mathrm{SmF}$ to produce succinic acid. By the end of the hydrolysis, a total glucose and FAN concentrations of $31.9 \mathrm{~g} \mathrm{~L}^{-1}$ and $280 \mathrm{mg} \mathrm{L}^{-1}$, respectively, were obtained. The glucose value was lower than when using commercial enzymes, where a concentration of $143 \mathrm{~g} \mathrm{~L}^{-1}$ was obtained. However, as the authors point out, such a high concentration is unfavorable for the growth of Actinobacillus succinogenes, which shows inhibition in the presence of glucose concentrations over $70 \mathrm{~g} \mathrm{~L}^{-1}$.

The study by Sun et al. [72], shows some remarkable components. First, following the trend of substituting traditional feedstocks (simple sugars), first by starch, then by wheat milling residues and bakery wastes, the authors investigated kitchen wastes for the hydrolysis and SmF step. Like many other residues, kitchen wastes are produced in large amounts, with the added characteristic of being highly heterogeneous, compared to starch or other wastes, e.g., bakery wastes [43]. Additionally, the idea of using different substrates for the SsF (bakery wastes) and the hydrolysis and SmF (kitchen wastes), has, from a practical point of view, many benefits. It is easy to imagine that some wastes should perform better than others to synthesize enzymes in the SsF. Furthermore, combining different substrates in different stages of the process, increases versatility and provides more options in terms of meeting specific targets, e.g., activities of enzymes, concentrations of sugars and FAN in the hydrolysis, etc. Furthermore, in this specific case, in which such 
a high concentration of sugars (obtained using commercial enzymes) is detrimental, SsF offers an oriented solution for the bioconversion.

A similar strategy was implemented for the production of lactic acid from food wastes [75]. SsF of kitchen wastes by A. awamori and A. oryzae was carried out for the production of amylases and proteases, respectively. Following that, SsF residues of the two strains (14 g each) were suspended together with $300 \mathrm{~g}$ of fresh kitchen wastes in $1 \mathrm{~L}$ of dionised water for hydrolysis. Remarkably high concentrations of glucose $\left(100.2 \pm 2.4 \mathrm{~g} \mathrm{~L}^{-1}\right)$ and FAN $\left(1081 \pm 70.2 \mathrm{mg} \mathrm{L}^{-1}\right)$ were obtained. The hydrolysates were used by Lactobacillus casei Shirota in SmF, reaching a lactic acid concentration of $94 \mathrm{~g} \mathrm{~L}^{-1}$. Moreover, the authors developed a techno-economic assessment of a simulation of the process within an industrial setting, which included the SsF step for on-site enzymes production [78].

In another study, SsF was used to produce a nutrient-rich supplement which could work as an alternative to the expensive yeast extract and inorganic chemicals typically employed in fermentations [73]. Sunflower meal, a protein rich residue obtained during sunflower's oil extraction, was used as the substrate in SsF. The fungi, A. oryzae, was grown on the meal $(5 \mathrm{~g})$ without the addition of any extra nutrients. After SsF the fermented residues were used in hydrolysis experiments of the same sunflower meal. In addition to the proteolytic enzymes, responsible for the liberation of FAN, the higher temperatures, typically required in the hydrolysis, promote fungal autolysis which yields nutrients such as those from yeast extract [47]. The resulting hydrolysate was then used as the nitrogen source in a SmF of glycerol (carbon source), to produce PHA by Cupriavidus necator. It is important to note that, as in previous cases, the ratio of fermented solids to fresh solids for the hydrolysis step, went from only around 1:9 to as low as 1:18. In fact, the best results for FAN were obtained when a total concentration of solids (dry basis) of $90 \mathrm{~g} \mathrm{~L}^{-1}$ was used in the hydrolysis (from which $5 \mathrm{~g}$ corresponded to the SsF residues). This is a critical point, since the proportion of SsF solids needed is many-fold smaller, the scale at which SsF experiments need to be conducted is relatively small. In a similar work, rapeseed meal residues were used in SsF for the production of a nitrogen rich medium [74]. In that case, after SsF, fermented meal was mixed with fresh meal at a ratio of 1:10, to carry out the liquid hydrolysis. The nitrogen rich product was added to crude glycerol for the production of PHA in SmF.

An alternative explored by Cunha et al. [63], was the utilization of SsF as a preparatory step. In their experiments, sugarcane bagasse -impregnated with a nutrient solution- was used as substrate support and enzyme inducer for the growth of $A$. niger. Following the SsF, a liquid nutrient solution was added to the remaining fermented solids and a SmF was carried out to produce cellulases. Then, they compared the efficiency of cellulose between their sequential method and a SmF. The positive effect of a preliminary SsF step was clear, with an endoglucanase productivity 3-fold higher compared to that only from SmF. The authors highlight the inducer effect of sugarcane bagasse to produce enzymes and the morphology of the fungi while growing on the solid-state pre-culture, in the form of dispersed filamentous compared to pellets in the SmF pre-culture.

On another example of utilizing SsF as a pretreatment step, Lunprom et al. [48], used the microalgae Chlorella sp. TISTR 8411 for the generation biomass which was later used as the substrate in anaerobic SsF. The residues where then hydrolysed and, finally, dark fermentation was carried out to manufacture biohydrogen.

\section{Discussion}

Currently, the possibility of valorising unexploited waste biomass through SsF is increasing the relevance of this technology. As shown in Section 3, the successful combination of SsF and SmF in a sequential process has been demonstrated for several substrates and products. There has been a clear evolution in the type of substrates used in the process. The earliest investigations focused on building a process starting from wheat [65], however, research has moved to residues from other processes. This switch is probably the result of 
the need to utilize cheaper substrates, the food versus fuel problem and the integration of the circular bioeconomy model.

In all the studies, SsF was used to produce enzymes for subsequent hydrolyses. Thus, as outlined by Webb et al. [66], the SsF-and the production of enzymes-is the cornerstone of the process. Several waste substrates have been employed for the generation of enzymes in the SsF, remarkably in most cases without requiring the addition of extra nutrients. Nevertheless, it is apparent from the literature, that this step is not regarded as the predominant aspect of the experiments reported. In many cases, a review of how this type of systems have been successfully applied for other substrates and products is lacking. Furthermore, efforts in the optimization of process conditions in the SsF stage are still far from optimal. Studies such as the recently carried out by Marzo et al. [51], devoted at the optimization of SsF and hydrolysis conditions, for the production of a feedstock which could later on be used in SmF, will be fundamental. Nonetheless, the success of SsF for the experiments has been consistent; this highlights the simplicity of this kind of processes and should encourage other labs to establish research lines following the sequential SsF-SmF concept.

$\mathrm{Up}$ to a certain degree, the combination of SsF and SmF in a sequential process has been investigated for a few organic residues and products in scattered small-scale experiments $[47,48,51,63-65,68-77]$. Typically, SsF is performed in flasks or Petri dishes with low amounts of substrates. Naturally, research should thrive for the scale-up of the SsF systems and the development of bioreactors and methods to solve the current hindrances. Nevertheless, progress in the field of SsF can be achieved in many ways and the development of more efficient and sophisticated bioreactors, should not be considered a pre-condition for its growth. It has been suggested that, conceptually, the prospects of carrying out the SsF and the $\mathrm{SmF}$ within a single system could have some advantages, with some work showing basic preliminary efforts $[62,63,79]$. The concept of a bioreactor in which SsF and SmF are integrated is attractive and innovative and could reduce the number of steps for separations and downstream of enzymes [53,62]. However, such bioreactor has yet to be developed.

Remarkably, due to the high enzyme activities attained in the SsF, a smaller amount of solids on this step can be used to generate the required enzymes to hydrolyse larger amount of solids in the subsequent SmF step. In some cases the ratio of solids in the SsF to solids in the $\mathrm{SmF}\left(\mathrm{SsF}_{\text {solids }}: \mathrm{SmF}_{\text {solids }}\right)$ can be as low as 1:30 [70,71]. Moreover, this ratio only indicates the solid masses and not the working volumes in hydrolyses (which include the water added). For example, sunflower meal (a residue from the sunflower oil industry) was used as the substrate in SsF [73]. In the experiments, after SsF of $5 \mathrm{~g}$ of solids, these were suspended in $500 \mathrm{~mL}$ of water and then $85 \mathrm{~g}$ of fresh solids (1:18) were added and hydrolyzed, thus, a SsF solids concentration of only $1 \%\left(\mathrm{w} \mathrm{v}^{-1}\right)$. Another example is the biorefinery concept developed in [69] where wheat milling residues were used to produce succinic acid. After milling $1 \mathrm{~kg}$ of wheat, three streams were obtained: one of wheat flour (714 g), other one of middlings (95 g) and another one of bran (191 g). Then, $21 \mathrm{~g}$ of bran were used in two separate SsF to produce the enzymes necessary to hydrolyse the middlings and the rest of the bran ( $265 \mathrm{~g}$ total), in a $1.06 \mathrm{~L}$ working volume hydrolysis. The ratio of SsF solids to $\mathrm{SmF}$ solids was $1: 12$, around $8 \% \mathrm{w} \mathrm{w}^{-1}$. Taking into account that the bulk density of wheat bran is on average $200 \mathrm{~kg} \mathrm{~m}^{-3}$, a volume of $0.10 \mathrm{~L}$ will be required for the SsF. This indicates that the volume for the SsF bioreactor can be ten times smaller than the volume of the hydrolysis/SmF bioreactor. Additionally, in most of the studies experimental work to establish the best $\mathrm{SsF}_{\text {solids }}: \mathrm{SmF}_{\text {solids }}$ is lacking; such optimization would improve the results of the hydrolysis and could potentially further reduce the amount of solids in the SsF. In conclusion, though scaling-up and experiments for the optimization of the hydrolysis are still needed, the literature shows that the SsF bioreactors size in such systems, will be considerably smaller than in the subsequent hydrolysis and SmF. 
An interesting factor that in many cases simplifies the processes is the optimal temperatures for microbial growth and enzymes activity. In most of the research gathered in this review, filamentous fungi were used for the SsF (prominently, A. awamori and A. oryzae). Those fungi work better at mild temperatures (optimum around $30{ }^{\circ} \mathrm{C}$ ). On the other hand, enzymes obtained from those microbes, such as amylases, proteases and cellulases, show enhanced activities at higher temperatures [80]. Specially cellulases, show great activities at temperatures over $50^{\circ} \mathrm{C}$, well over the optimum growth temperature of the fungi, which hampers their growth in the SmF. Moreover, some authors have suggested that high temperatures can also lead to fungal autolysis, releasing nutrients contained within the fungal biomass and enhancing the process [47,69-71,81].

Currently, generic enzyme cocktails are commercially available, however, there is an increasing acceptance that this 'one-size-fits-all' approach is ineffective [82]. In nature, decomposition of organic matter is accomplished through the progressive action of several organisms that produce multiple enzymes rather than by a single organism [83]. For example, the decomposition of cellulose requires endoglucanases, exoglucanases and $\beta$-glucosidades. Trichoderma reseei, the most important fungus for cellulase production, bears high levels of endo- and exo-glucanases; however, it lacks sufficient $\beta$-glucosidades. Therefore other fungi (typically from Aspergillus spp.) are necessary in the hydrolysis of cellulose [56]. Expectedly, a more effective deconstruction of complex carbohydrates and nutrients in organic residues should require specialized enzymes mixtures. Some elementary investigations have for example target the production of one sugar rich stream and one nitrogen rich stream, by the growth of microbes in $\mathrm{SsF}$ that can produce the specific enzymes required for such hydrolyses. An integrated SsF-SmF system could be tailor-made in such a way that, multiple microorganisms and substrates are combined to provide the best enzyme mixture for a specific organic residue or product.

From an economic perspective, the establishment of on-site production of enzymes through SsF of organic residues, should reduce expenses in the overall processes $[30,66]$. Moreover, results have shown that fungal strains are usually robust and can grow without requiring the addition of extra nutrients. Additionally, the development of new strains, able to cope better with the processes is already considered and could make it even more attractive [30]. Furthermore, another advantage of a sequential SsF-SmF is that unlike in process involving only SsF, the downstream required will be only that one after SmF. Thus, a sequential SsF-SmF eliminates the need of a downstream step which is considered to be one of the main challenges in SsF development [16]. As shown in the revised literature, after $\mathrm{SsF}$, the enzymes can be extracted with a liquid and added to the hydrolysis medium containing fresh substrates. Alternatively, SsF solids containing the enzymes can be directly added to the hydrolysis medium. Studies devoted to defining the best method for the addition of enzymes to the hydrolysis would probably be fundamental in the development of SsF-SmF integrated systems.

Figure 4 shows the potential schemes for sequential SsF-SmF. System A shows the basic process in which a single organic residue is used for both, the generation of enzymes in $\mathrm{SsF}$ and as the substrate for hydrolysis and subsequent $\mathrm{SmF}$ (for example in the process described in [65]). System B shows a process which combines two substrates, one is used in the generation of the enzyme complex which later on hydrolyses the second substrate (as in the case described in [72]). System C tries to illustrate a more complex process, in which three substrates are involved. Such process could for example use substrate A to produce enzymes able to liberate carbohydrates, e.g., cellulases, substrate B could be used to produce enzymes able to liberate nitrogen, e.g., proteases. Later, those enzymes could be used to hydrolyze substrate 3, producing a feedstock for SmF. Naturally, this is only one of the multiple possible configurations. As discussed above, the breaking down of complex polymers in organic residues requires the action of several enzymes in order to be more effective. Conveniently, a vast amount of the literature is already related to the production of a wide variety of enzymes from numerous organic residues. Further studies should focus on the combination of SsF processes to produce a target cocktail of 
enzymes able to hydrolyze effectively a specific substrate. Additionally, since the multiple enzymes could have various optimum conditions, studies on the development of optimized hydrolysis processes will be required to guarantee that the cocktail as a whole works at its best. Such appropriate selection and combination of substrates, to attain enhanced enzymatic products, together with optimized hydrolysis processes, will further benefit the sequential process [60].

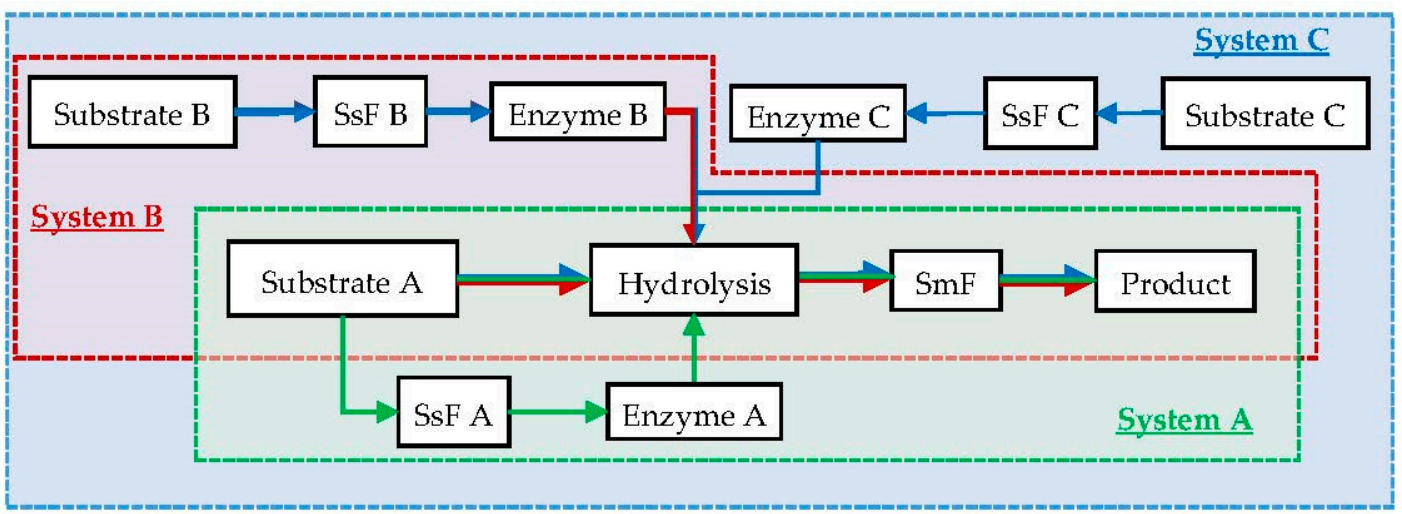

Figure 4. Diagram of different schemes for sequential SsF and SmF. The colour of the arrows indicates the system to which they belong (green for $\mathrm{A}$, red for B and blue for C).

Author Contributions: All authors have contributed equally to the production of this manuscript. All authors have read and agreed to the published version of the manuscript.

Funding: This research received no external funding.

Institutional Review Board Statement: Not applicable.

Informed Consent Statement: Not applicable.

Data Availability Statement: Not applicable.

Conflicts of Interest: The authors declare no conflict of interest.

\section{References}

1. López-Gómez, J.P.; Manan, M.A.; Webb, C. Solid-state fermentation of food industry wastes. In Food Industry Wastes, 2nd ed.; Kosseva, M.R., Webb, C., Eds.; Elsevier: Amsterdam, The Netherlands, 2020; pp. 135-161. [CrossRef]

2. Pandey, A. Recent process developments in solid-state fermentation. Process Biochem. 1992, 27, 109-117. [CrossRef]

3. Pandey, A.; Soccol, C.R.; Larroche, C. Current Developments in Solid-State Fermentation; Springer: New York, NY, USA, 2008. [CrossRef]

4. SciVerse Scopus, Scopus-Analyze Search Results. 2021. Available online: https://www.scopus.com/term/analyzer.uri?sid=a1d8 1e2ded735f2ba3d07d032dc4da30\&origin=resultslist\&src=s\&s=\%28TITLE-ABS-KEY+\%28solid+state+fermentation \%29+AND+ TITLE-ABS-KEY+\%28solid-state+fermentation\%29\%29\&sort=plf-f\&sdt=b\&sot=b\&sl=87\&count=7442\&analyzeRes (accessed on 12 February 2021).

5. Soccol, C.R.; da Costa, E.S.F.; Letti, L.A.J.; Karp, S.G.; Woiciechowski, A.L.; de Souza Vandenberghe, L.P. Recent developments and innovations in solid state fermentation. Biotechnol. Res. Innov. 2017, 1, 52-71. [CrossRef]

6. W.I.P. Organization, WIPO IP Portal. 2021. Available online: https://patentscope.wipo.int/search/en/result.jsf?_vid=P21KNFZ6E-29561 (accessed on 13 April 2021).

7. Costa, J.A.V.; Treichel, H.; Kumar, V.; Pandey, A. Advances in Solid-State Fermentation. In Current Developments in Biotechnology and Bioengineering; Elsevier: Amsterdam, The Netherlands, 2018. [CrossRef]

8. Manan, M.A.; Webb, C. Modern microbial solid state fermentation technology for future biorefineries for the production of added-value products. Biofuel Res. J. 2017, 4, 730-740. [CrossRef]

9. Thomas, L.; Larroche, C.; Pandey, A. Current developments in solid-state fermentation. Biochem. Eng. J. 2013, 81, 146-161. [CrossRef]

10. Oviedo-Lopera, J.C.; Zartha-Sossa, J.W.; Zapata-Ruiz, D.L.; Bohorquez-Naranjo, I.; Morales-Arevalo, K.S. Systematic Review and Study of S Curves for Biomass Quantification in Solid-state Fermentation (SSF) and Digital Image Processing (DIP) Applied to Biomass Measurement in Food Processes. Recent Pat. Biotechnol. 2020, 14, 194-202. [CrossRef] 
11. Mitchell, D.A.; Pitol, L.O.; Biz, A.; Finkler, A.T.J.; de Lima Luz, L.F., Jr.; Krieger, N. Design and Operation of a Pilot-Scale Packed-Bed Bioreactor for the Production of Enzymes by Solid-State Fermentation. In Solid State Fermentation. Advances in Biochemical Engineering/Biotechnology; Steudler, S., Werner, A., Cheng, J., Eds.; Springer: Berlin, Germany, 2019; Volume 169, pp. 27-50. [CrossRef]

12. Arora, S.; Rani, R.; Ghosh, S. Bioreactors in solid state fermentation technology: Design, applications and engineering aspects. J. Biotechnol. 2018, 269, 16-34. [CrossRef] [PubMed]

13. Manan, M.A.; Webb, C. Design Aspects of Solid State Fermentation as Applied to Microbial Bioprocessing. J. Appl. Biotechnol. Bioeng. 2017, 4. [CrossRef]

14. Ashok, A.; Doriya, K.; Rao, D.R.M.; Kumar, D.S. Design of solid state bioreactor for industrial applications: An overview to conventional bioreactors. Biocatal. Agric. Biotechnol. 2017, 9, 11-18. [CrossRef]

15. Leite, P.; Sousa, D.; Fernandes, H.; Ferreira, M.; Costa, A.R.; Filipe, D.; Gonçalves, M.; Peres, H.; Belo, I.; Salgado, J.M. Recent advances in production of lignocellulolytic enzymes by solid-state fermentation of agro-industrial wastes. Curr. Opin. Green Sustain. Chem. 2020, 27, 100407. [CrossRef]

16. Kumar, V.; Ahluwalia, V.; Saran, S.; Kumar, J.; Patel, A.K.; Singhania, R.R. Recent developments on solid-state fermentation for production of microbial secondary metabolites: Challenges and solutions. Bioresour. Technol. 2020, 124566. [CrossRef]

17. Verduzco-Oliva, R.; Gutierrez-Uribe, J.A. Beyond enzyme production: Solid state fermentation (SSF) as an alternative approach to produce antioxidant polysaccharides. Sustainability 2020, 12, 495. [CrossRef]

18. Soccol, C.R.; Vandenberghe, L.P.S.; Rodrigues, C.; Medeiros, A.B.P.; Larroche, C.; Pandey, A. Production of Organic Acids by Solid-state Fermentation. In Current Developments in Solid-State Fermentation; Springer: New York, NY, USA, 2009; pp. 205-229. [CrossRef]

19. Cerda, A.; Artola, A.; Barrena, R.; Font, X.; Gea, T.; Sánchez, A. Innovative Production of Bioproducts From Organic Waste Through Solid-State Fermentation, Front. Sustain. Food Syst. 2019, 3, 63. [CrossRef]

20. Sadh, P.K.; Duhan, S.; Duhan, J.S. Agro-industrial wastes and their utilization using solid state fermentation: A review. Bioresour. Bioprocess. 2018, 5, 1-15. [CrossRef]

21. Lizardi-Jiménez, M.A.; Hernández-Martínez, R. Solid state fermentation (SSF): Diversity of applications to valorize waste and biomass. 3 Biotech 2017, 7, 44. [CrossRef]

22. Yazid, N.A.; Barrena, R.; Komilis, D.; Sánchez, A. Solid-State Fermentation as a Novel Paradigm for Organic Waste Valorization: A Review. Sustainability 2017, 9, 224. [CrossRef]

23. Kosseva, M.R. Recovery of Commodities from Food Wastes Using Solid-State Fermentation. In Food Industry Wastes, 1st ed.; Elsevier: Amsterdam, The Netherlands, 2013; pp. 77-102. [CrossRef]

24. Couto, S.R.; Sanromán, M.Á. Application of solid-state fermentation to food industry-A review. J. Food Eng. 2006, 76, 291-302. [CrossRef]

25. Raimbault, M. General and microbiological aspects of solid substrate fermentation, Electron. J. Biotechnol. 1998, 1, 174-188 [CrossRef]

26. Pandey, A.; Soccol, C.R.; Mitchell, D. New developments in solid state fermentation: I-bioprocesses and products. Process. Biochem. 2000, 35, 1153-1169. [CrossRef]

27. Pandey, A. Solid-state fermentation. Biochem. Eng. J. 2003, 13, 81-84. [CrossRef]

28. Castilho, L.R.; Mitchell, D.A.; Freire, D.M.G. Production of polyhydroxyalkanoates (PHAs) from waste materials and by-products by submerged and solid-state fermentation. Bioresour. Technol. 2009, 100, 5996-6009. [CrossRef]

29. Viniegra-González, G.; Favela-Torres, E. Why solid-state fermentation seems to be resistant to catabolite repression? Food Technol. Biotechnol. 2006, 44, 397-406.

30. Shinkawa, S.; Mitsuzawa, S. Feasibility study of on-site solid-state enzyme production by Aspergillus oryzae, Biotechnol. Biotechnol. Biofuels 2020, 13, 1-15. [CrossRef]

31. de Castro, R.J.S.; Sato, H.H. Enzyme Production by Solid State Fermentation: General Aspects and an Analysis of the Physicochemical Characteristics of Substrates for Agro-industrial Wastes Valorization. Waste Biomass Valorization 2015, 6, 1085-1093. [CrossRef]

32. Vandenberghe, L.P.S.; Pandey, A.; Carvalho, J.C.; Letti, L.A.J.; Woiciechowski, A.L.; Karp, S.G.; Thomaz-Soccol, V.; MartínezBurgos, W.J.; Penha, R.O.; Herrmann, L.W.; et al. Solid-state fermentation technology and innovation for the production of agricultural and animal feed bioproducts. Syst. Microbiol. Biomanufacturing 2020, 1, 142-165. [CrossRef]

33. López-Gómez, J.P.; Pérez-Rivero, C.; Webb, C. Investigating a non-destructive alternative for a preliminary evaluation of fungal growth in solid state fermentations. J. Microbiol. Methods 2019, 160, 60-67. [CrossRef] [PubMed]

34. Durand, A.; Renaud, R.; Almanza, S.; Maratray, J.; Diez, M.; Desgranges, C. Solid state fermentation reactors: From lab scale to pilot plant. Biotechnol. Adv. 1993, 11, 591-597. [CrossRef]

35. Mitchell, D.A.; Luz, L.F.d.; Krieger, N.; Berovič, M. Bioreactors for Solid-State Fermentation. In Comprehensive Biotechnology, 2nd ed.; Moo-Yong, M., Ed.; Elsevier: Amsterdam, The Netherlands, 2011; pp. 347-360. [CrossRef]

36. Lüth, P.; Eiben, U. Solid-State Fermenter and Method for Solid-State Fermentation, US6620614B1. 2003. Available online: https:/ / patents.google.com/patent/US6620614?oq=forced+aeration+beauveria (accessed on 10 May 2021).

37. Mazumdar-Shaw, K.; Suryanarayan, S. Commercialization of a novel fermentation concept. Adv. Biochem. Eng. Biotechnol. 2003, 85, 29-42. [CrossRef] 
38. Boratyński, F.; Szczepańska, E.; Grudniewska, A.; Olejniczak, T. Microbial kinetic resolution of aroma compounds using solid-state fermentation. Catalysts 2018, 8. [CrossRef]

39. Martínez, O.; Sánchez, A.; Font, X.; Barrena, R. Enhancing the bioproduction of value-added aroma compounds via solid-state fermentation of sugarcane bagasse and sugar beet molasses: Operational strategies and scaling-up of the process. Bioresour. Technol. 2018, 363, 136-144. [CrossRef]

40. Dulf, F.V.; Vodnar, D.C.; Dulf, E.-H.; Pintea, A. Phenolic compounds, flavonoids, lipids and antioxidant potential of apricot (Prunus armeniaca L.) pomace fermented by two filamentous fungal strains in solid state system. Chem. Cent. J. 2017, 11, 92. [CrossRef] [PubMed]

41. Alexandri, M.; López-Gómez, J.P.; Olszewska-Widdrat, A.; Venus, J. Valorising Agro-industrial Wastes within the Circular Bioeconomy Concept: The Case of Defatted Rice Bran with Emphasis on Bioconversion Strategies. Fermentation $2020,6,42$. [CrossRef]

42. Stegmann, P.; Londo, M.; Junginger, M. The circular bioeconomy: Its elements and role in European bioeconomy clusters. Resour. Conserv. Recycl. X 2020, 6, 100029. [CrossRef]

43. López-Gómez, J.P.; Pérez-Rivero, C.; Venus, J. Valorisation of solid biowastes: The lactic acid alternative. Process. Biochem. 2020, 99, 222-235. [CrossRef]

44. Kumar, B.; Verma, P. Enzyme mediated multi-product process: A concept of bio-based refinery. Ind. Crops Prod. 2020, 154, 112607. [CrossRef]

45. Nwobi, A.; Cybulska, I.; Tesfai, W.; Shatilla, Y.; Rodríguez, J.; Thomsen, M.H. Simultaneous saccharification and fermentation of solid household waste following mild pretreatment using a mix of hydrolytic enzymes in combination with Saccharomyces cerevisiae. Appl. Microbiol. Biotechnol. 2014, 99, 929-938. [CrossRef]

46. Ravindran, R.; Hassan, S.S.; Williams, G.A.; Jaiswal, A.K. A review on bioconversion of agro-industrial wastes to industrially important enzymes. Bioengineering 2018, 5, 93. [CrossRef]

47. Wang, R.; Shaarani, S.M.; Godoy, L.C.; Melikoglu, M.; Vergara, C.S.; Koutinas, A.; Webb, C. Bioconversion of rapeseed meal for the production of a generic microbial feedstock. Enzyme Microb. Technol. 2010, 47, 77-83. [CrossRef]

48. Lunprom, S.; Phanduang, O.; Salakkam, A.; Liao, Q.; Reungsang, A. A sequential process of anaerobic solid-state fermentation followed by dark fermentation for bio-hydrogen production from Chlorella sp. Int. J. Hydrogen Energy 2019, 44, 3306-3316. [CrossRef]

49. Kumar, B.; Verma, P. Biomass-based biorefineries: An important architype towards a circular economy. Fuel 2021, $288,119622$. [CrossRef]

50. Grand View Research, Enzymes Market Size, Share \& Trends Analysis Report by Application (Industrial Enzymes, Specialty Enzymes), By Product (Carbohydrase, Proteases, Lipases), by Source, by Region, and Segment Forecasts, 2020-2027, San Francisco. 2020. Available online: https://www.grandviewresearch.com/industry-analysis/enzymes-industry (accessed on 10 May 2021).

51. Marzo, C.; Díaz, A.B.; Caro, I.; Blandino, A. Conversion of exhausted sugar beet pulp into fermentable sugars from a biorefinery approach. Foods 2020, 9, 1351. [CrossRef] [PubMed]

52. Klein-Marcuschamer, D.; Oleskowicz-Popiel, P.; Simmons, B.A.; Blanch, H.W. The challenge of enzyme cost in the production of lignocellulosic biofuels. Biotechnol. Bioeng. 2012, 109, 1083-1087. [CrossRef] [PubMed]

53. Singh, A.; Jasso, R.M.R.; Gonzalez-Gloria, K.D.; Rosales, M.; Cerda, R.B.; Aguilar, C.N.; Singhania, R.R.; Ruiz, H.A. The enzyme biorefinery platform for advanced biofuels production. Bioresour. Technol. Rep. 2019, 7, 100257. [CrossRef]

54. Ferreira, R.D.G.; Azzoni, A.R.; Freitas, S. Techno-economic analysis of the industrial production of a low-cost enzyme using E. coli: The case of recombinant $\beta$-glucosidase. Biotechnol. Biofuels 2018, 11, 1-13. [CrossRef] [PubMed]

55. Liu, G.; Zhang, J.; Bao, J. Cost evaluation of cellulase enzyme for industrial-scale cellulosic ethanol production based on rigorous Aspen Plus modeling. Bioprocess. Biosyst. Eng. 2016, 39, 133-140. [CrossRef] [PubMed]

56. Ellilä, S.; Fonseca, L.; Uchima, C.; Cota, J.; Goldman, G.H.; Saloheimo, M.; Sacon, V.; Siika-Aho, M. Development of a low-cost cellulase production process using Trichoderma reesei for Brazilian biorefineries. Biotechnol. Biofuels 2017, 10, 1-17. [CrossRef]

57. Johnson, E. Integrated enzyme production lowers the cost of cellulosic ethanol. Biofuels Bioprod. Biorefining 2016, 10, 164-174. [CrossRef]

58. Sukumaran, R.K.; Christopher, M.; Kooloth-Valappil, P.; Sreeja-Raju, A.; Mathew, R.M.; Sankar, M.; Puthiyamadam, A.; Adarsh, V.P.; Aswathi, A.; Rebinro, V.; et al. Addressing challenges in production of cellulases for biomass hydrolysis: Targeted interventions into the genetics of cellulase producing fungi. Bioresour. Technol. 2021, 329, 124746. [CrossRef]

59. Wang, R.; Godoy, L.C.; Shaarani, S.M.; Melikoglu, M.; Koutinas, A.; Webb, C. Improving wheat flour hydrolysis by an enzyme mixture from solid state fungal fermentation. Enzyme Microb. Technol. 2009, 44, 223-228. [CrossRef]

60. Steudler, S.; Werner, A.; Walther, T. It Is the Mix that Matters: Substrate-Specific Enzyme Production from Filamentous Fungi and Bacteria Through Solid-State Fermentation. In Solid State Fermentation. Advances in Biochemical Engineering/Biotechnology; Steudler, S., Werner, A., Cheng, J., Eds.; Springer: Berlin, Germany, 2019; Volume 169, pp. 51-82. [CrossRef]

61. Teigiserova, D.A.; Bourgine, J.; Thomsen, M. Closing the loop of cereal waste and residues with sustainable technologies: An overview of enzyme production via fungal solid-state fermentation. Sustain. Prod. Consum. 2021, 27, 845-857. [CrossRef]

62. Farinas, C.S. Developments in solid-state fermentation for the production of biomass-degrading enzymes for the bioenergy sector. Renew. Sustain. Energy Rev. 2015, 52, 179-188. [CrossRef] 
63. Cunha, F.M.; Esperança, M.N.; Zangirolami, T.C.; Badino, A.C.; Farinas, C.S. Sequential solid-state and submerged cultivation of Aspergillus niger on sugarcane bagasse for the production of cellulase. Bioresour. Technol. 2012, 112, 270-274. [CrossRef] [PubMed]

64. Viesturs, U.E.; Strikauska, S.V.; Leite, M.P.; Berzins, A.J.; Tengerdy, R.P. Combined submerged and solid substrate fermentation for the bioconversion of lignocellulose. Biotechnol. Bioeng. 1987, 30, 282-288. [CrossRef] [PubMed]

65. Botella, C.; Diaz, A.B.; Wang, R.; Koutinas, A.; Webb, C. Particulate bioprocessing: A novel process strategy for biorefineries. Process. Biochem. 2009, 44, 546-555. [CrossRef]

66. Webb, C.; Koutinas, W.R.; Wang, R. Developing a sustainable bioprocessing strategy based on a generic feedstock. Adv. Biochem. Eng. Biotechnol. 2004, 87, 195-268. [CrossRef]

67. Webb, C.; Wang, R. Development of a Generic Fermentation Feedstock from Whole Wheat Flour. In Cereals; Springer: Boston, MA, USA, 1997; pp. 205-218. [CrossRef]

68. Du, C.; Lin, S.K.C.; Koutinas, A.; Wang, R.; Dorado, P.; Webb, C. A wheat biorefining strategy based on solid-state fermentation for fermentative production of succinic acid. Bioresour. Technol. 2008, 99, 8310-8315. [CrossRef]

69. Dorado, M.P.; Lin, S.K.C.; Koutinas, A.; Du, C.; Wang, R.; Webb, C. Cereal-based biorefinery development: Utilisation of wheat milling by-products for the production of succinic acid. J. Biotechnol. 2009, 143, 51-59. [CrossRef]

70. Leung, C.C.J.; Cheung, A.S.Y.; Zhang, A.Y.-Z.; Lam, K.F.; Lin, C.S.K. Utilisation of waste bread for fermentative succinic acid production. Biochem. Eng. J. 2012, 65, 10-15. [CrossRef]

71. Zhang, A.Y.; Sun, Z.; Leung, C.C.J.; Han, W.; Lau, K.Y.; Li, M.; Lin, C.S.K. Valorisation of bakery waste for succinic acid production. Green Chem. 2013, 15, 690-695. [CrossRef]

72. Sun, Z.; Li, M.; Qi, Q.; Gao, C.; Lin, C.S.K. Mixed Food Waste as Renewable Feedstock in Succinic Acid Fermentation. Appl. Biochem. Biotechnol. 2014, 174, 1822-1833. [CrossRef]

73. Kachrimanidou, V.; Kopsahelis, N.; Chatzifragkou, A.; Papanikolaou, S.; Yanniotis, S.; Kookos, I.; Koutinas, A.A. Utilisation of By-Products from Sunflower-Based Biodiesel Production Processes for the Production of Fermentation Feedstock. Waste Biomass Valorization 2013, 4, 529-537. [CrossRef]

74. García, I.L.; López, J.A.; Dorado, M.P.; Kopsahelis, N.; Alexandri, M.; Papanikolaou, S.; Villar, M.A.; Koutinas, A.A. Evaluation of by-products from the biodiesel industry as fermentation feedstock for poly(3-hydroxybutyrate-co-3-hydroxyvalerate) production by Cupriavidus necator. Bioresour. Technol. 2013, 130, 16-22. [CrossRef]

75. Kwan, T.H.; Hu, Y.; Lin, C.S.K. Valorisation of food waste via fungal hydrolysis and lactic acid fermentation with Lactobacillus casei Shirota. Bioresour. Technol. 2016, 217, 129-136. [CrossRef]

76. Tsakona, S.; Kopsahelis, N.; Chatzifragkou, A.; Papanikolaou, S.; Kookos, I.K.; Koutinas, A.A. Formulation of fermentation media from flour-rich waste streams for microbial lipid production by Lipomyces starkeyi. J. Biotechnol. 2014, 189, 36-45. [CrossRef] [PubMed]

77. Khonngam, T.; Salakkam, A. Bioconversion of sugarcane bagasse and dry spent yeast to ethanol through a sequential process consisting of solid-state fermentation, hydrolysis, and submerged fermentation. Biochem. Eng. J. 2019, 150, 107284. [CrossRef]

78. Kwan, T.H.; Hu, Y.; Lin, C.S.K. Techno-economic analysis of a food waste valorisation process for lactic acid, lactide and poly(lactic acid) production. J. Clean. Prod. 2018, 181, 72-87. [CrossRef]

79. Cunha, F.M.; Esperança, M.N.; Florencio, C.; Vasconcellos, V.M.; Farinas, C.S.; Badino, A.C. Three-phasic fermentation systems for enzyme production with sugarcane bagasse in stirred tank bioreactors: Effects of operational variables and cultivation method. Biochem. Eng. J. 2015, 97, 32-39. [CrossRef]

80. Herlet, J.; Kornberger, P.; Roessler, B.; Glanz, J.; Schwarz, W.H.; Liebl, W.; Zverlov, V.V. A new method to evaluate temperature vs. $\mathrm{pH}$ activity profiles for biotechnological relevant enzymes. Biotechnol. Biofuels 2017, 10, 1-12. [CrossRef]

81. Melikoglu, M.; Lin, C.S.K.; Webb, C. Solid state fermentation of waste bread pieces by Aspergillus awamori: Analysing the effects of airflow rate on enzyme production in packed bed bioreactors. Food Bioprod. Process. 2015, 95, 63-75. [CrossRef]

82. Lopes, A.M.; Filho, E.X.F.; Moreira, L.R.S. An update on enzymatic cocktails for lignocellulose breakdown. J. Appl. Microbiol. 2018, 125, 632-645. [CrossRef] [PubMed]

83. Bischof, R.H.; Ramoni, J.; Seiboth, B. Cellulases and beyond: The first 70 years of the enzyme producer Trichoderma reesei. Microb. Cell Fact. 2016, 15, 1-13. [CrossRef] [PubMed] 